\title{
Perceptions of milk producers from Divinópolis, Minas Gerais, regarding Rhipicephalus (Boophilus) microplus control
}

\author{
Percepcãa dos produtores de leite de Divinópolis, Minas Gerais, \\ sobre o controle de Rhipicephalus (Boophilus) microplus
}

\author{
Christiane Maria Barcellos Magalhães da Rocha ${ }^{1 *}$; Romário Cerqueira Leite²; Fábio Raphael Pascoti Bruhn; \\ Antônio Marcos Guimarães'; John Furlong ${ }^{3}$
}

${ }^{1}$ Laboratório de Epidemiologia do Departamento de Medicina Veterinária, Universidade Federal de Lavras - UFLA

${ }^{2}$ Escola de Veterinária, Universidade Federal de Minas Gerais - UFMG

${ }^{3}$ Centro Nacional de Pesquisa de Gado de Leite, Empresa Brasileira de Pesquisa Agropecuária - EMBRAPA

Receveid February 22, 2011

Accepted May 26, 2011

\begin{abstract}
Semi-systematized interviews were conducted with 100 dairy cattle producers in the municipality of Divinópolis, Minas Gerais, with the aim of ascertaining their perceptions regarding the importance of Rhipicephalus (Boophilus) microplus and of combating it. Content analysis was performed and the frequency distribution of each of the variables was used to construct profiles of the producers interviewed. The production losses caused by ticks were perceived incompletely by the producers, who were unaware of the pathogen transmission caused by the parasite and the indirect losses through combating it, such as the cost of acaricide and labor. The combat operations were performed in a traditional manner, with an excessive number of inefficient treatments that aimed to control the level of infestation at that moment. The quality of the acaricide dipping/spraying applied was affected by the quality of the equipment used to apply the products, lack of knowledge of the mode of action of these products, lack of the specific information needed and lack of motivation caused by unawareness of the disadvantages of chemical combat. It was concluded that the lack of knowledge about combat methods and the acceptance of endemicity of the parasitosis were impediments to changing the realities encountered.
\end{abstract}

Keywords: Rhipicephalus (Boophilus) microplus, cattle tick, microregion, knowledge, attitude.

\section{Resumo}

Entrevistas semissistematizadas foram aplicadas a 100 produtores de bovinos leiteiros do município de Divinópolis, Minas Gerais, com o objetivo de verificar a sua percepção sobre a importância de Rhipicephalus (Boophilus) microplus e seu combate. Foi feita "análise de conteúdo" e a distribuiçáo de frequência de cada uma das variáveis para a construçáo de perfis dos produtores entrevistados. Os prejuízos causados à produçáo pelo carrapato são percebidos de forma incompleta pelos produtores, que ignoram a transmissão de patógenos pelo parasito e as perdas indiretas pelo combate, como o custo do carrapaticida e da mão de obra. O combate era feito de maneira tradicional com número excessivo de tratamentos ineficientes, com o objetivo de controlar o nível da infestação naquele momento. A qualidade da aplicação do banho carrapaticida foi afetada pelo equipamento utilizado para aplicação dos produtos, pelo desconhecimento do modo de ação desses, pela falta de informações específicas necessárias e pela falta de motivação gerada no desconhecimento das desvantagens do combate químico. Conclui-se que a falta de conhecimento sobre modos de combate e a aceitação da endemicidade da parasitose impedem a mudança da realidade encontrada.

Palavras-chave: Rhipicephalus (Boophilus) microplus, carrapato do boi, microrregiấo, conhecimento, atitude.

\footnotetext{
*Corresponding author: Christiane Maria Barcellos Magalhães da Rocha Christiane Maria Barcellos Magalhães da Rocha

Laboratório de Epidemiologia, Departamento de Medicina Veterinária,

Universidade Federal de Lavras - UFLA, CP 3037,

CEP 37200-000, Lavras, MG, Brasil

e-mail: rochac@dmv.ufla.br
} 


\section{Introduction}

Brazil has the biggest commercial cattle herd in the world. Rhipicephalus (Boophilus) microplus is the most important ectoparasite, causing losses that have been calculated as two billion dollars per year (GRISI et al., 2002). In addition, it brings risks to human and animal health through exposure to acaricide products and residues in meat and milk.

Despite the great losses to the country, the losses produced within each farm property seem to be downplayed by the farm owners. They mostly place little importance on systematized combat against this parasite. Tick control is done without taking into consideration technical criteria and the characteristics of the biological cycle, and there is a great distance between the technical knowledge available and the ways in which it is used (AMARAL et al., 2011a,b; ROCHA et al., 2006; CAMPOS JÚNIOR; OLIVEIRA, 2005). Among the most damaging consequences of this incorrect use of control products are the rapid development of resistance to acaricides (SANTOS et al., 2009) and the buildup of chemical residues in animal tissues and within the environment.

The farm producers' perceptions regarding the tick $R$. (B.) microplus is drawn more from practical experience than from acquisition of knowledge, which leads to greater difficulty in controlling this ectoparasite (ROCHA et al., 2006, 2011).

Considering that control measures against $R$. (B.) microplus have been implemented by farm owners, the present study was conducted with the aim of ascertaining how this control was done and what knowledge these producers had regarding the damage caused by ticks. This study was compared with the study by Rocha et al. (2006), who applied the same methodology in Passos, in the south of Minas Gerais, and the study by Amaral et al. (2011b). From this, directions that might minimize the losses and improve the control were indicated.

\section{Material and Methods}

One hundred milk producers in the municipality of Divinópolis, Minas Gerais, were interviewed about tick control in their farm properties.

The interviewees were drawn randomly from the milk producers' register if the Minas Gerais Institute of Agriculture and Livestockrearing (IMA) of 1993, and from information from the Department of Agriculture of Divinópolis. Divinópolis is located at 20 8' $20^{\prime \prime} \mathrm{S}$ and $44^{\circ} 53^{\prime} 2^{\prime \prime} \mathrm{W}$, in microregion 186 of the state of Minas Gerais, with an area of $716 \mathrm{~km}^{2}$ and a mean annual temperature of $23^{\circ} \mathrm{C}$. The rural properties were organized according to community, and the great majority consisted of small producers, who were classified by the size of their landholdings, effective cattle herd size, production and productivity.

The total number of farm properties in the municipality was 318 , distributed among 18 communities. For this study, 134 interviews were conducted between May and December 1994, distributed proportionally among the communities.

For the present study, it was decided to analyze 100 questionnaires out of the 134 that were filled out, through the following exclusion criteria: 1) 27 had undergone pretests; 2) four presented very specific situations that made it difficult to analyze them together with the others; 3 ) three were excluded because their herds only consisted of five cows.

The percentage of the producers evaluated was $31 \%$, distributed in a representative manner among the rural communities.

The qualitative methodology, from the construction of the forms and processing of the interviews to the data analysis and presentation of the results, was conducted in accordance with Rocha (1996), based on Minayo (1993) and Gil (1991), as described below.

Descriptive analysis was performed on all the variables. For each question asked, a description was made, with an indication of how the individuals in the group varied, emphasizing what was typical in the sample studied in order to extract profiles and conclusions.

It was determined that each of the questions would correspond to one variable. Open responses were categorized by means of content analysis (MINAYO, 1993), in which the data for each variable were described and the features that were most frequent in the study sample were emphasized, such that through logic, conclusions could be extracted. The responses were compared with knowledge about ticks in the literature, and were classified as correct or incorrect. Three groups of information on tick combat were used: 1) the importance that producers gave to ticks regarding milk production losses; 2) the ways of combating ticks that were used; and 3) the producers' knowledge about other ways of combating ticks. Several questions were asked in relation to each information group.

The variables used to characterize the producers' perceptions of the influence of ticks on the production process related to the losses caused to the animals and the production, thereby surveying the mechanisms through which these losses arise and the transmission of pathogens by this vector. The combat methods used were described in terms of the frequency of acaricide treatments, dilution of the solution, volume per animal, products, application and protection equipment used and understanding of the tick resistance process. To characterize how the producers perceived the control method that they used, they were asked about the costs and labor relating to control, their knowledge of combat methods other than the ones that they used and their sources of information.

\section{Results and Discussion}

Farm properties of up to 50 ha accounted for $70 \%$ of the properties visited. Properties of between 51 and 100 ha accounted for $21 \%$ and properties over 100 ha only for $9 \%$. Most of the farm properties used their entire area for dairy cattle, and only 39\% used a significant proportion of their land for other activities. Among the farms, $64 \%$ produced up to $100 \mathrm{~L}$ of milk/day on average through the year, of which $50 \%$ produced up to $50 \mathrm{~L} /$ day. Only $15 \%$ of the farms produced between 100 and $150 \mathrm{~L} /$ day and $21 \%$ more than $150 \mathrm{~L} /$ day. In $71 \%$ of the properties, the production per cow/day was up to eight liters, which demonstrated the low use of technology on these farms. Among the other 29\%, only $2 \%$ said that their average milk production per cow was greater than $15 \mathrm{~L}$. 
The losses to the herd and the production losses that the producers perceived to be caused by ticks were one of the factors that led them to implement combat measures. Table 1 shows that the producers in Minas Gerais were well aware of the production losses characterized by delayed growth, weight loss and diminished milk production. Only 20\% of the producers referred to the losses as "parasite afflictions", without making it clear whether this described a disease or a state of weakness that left the animals anemic, with weight losses, lowered head and discharges from the eyes. It is likely that there was some confusion with generalized weakening caused by blood loss. The producers in Divinópolis, Minas Gerais, seemed to be unaware of the losses relating to the costs and toxicological risks of combating ticks. When asked about the mechanisms through which ticks cause increased mortality among cattle, $28 \%$ said that ticks generally did not affect the mortality rate in the herd, or that death would only occur if a significant volume of blood was lost, which would only be possible if the number of ticks was very large. Among the other $72 \%$, less than $20 \%$ correlated mortality with the illnesses caused after pathogen transmission by ticks, or with the establishment of "parasite affliction". The great majority (87\%) responded that ticks could cause diseases, but only in a general manner, since only $15 \%$ cited the "affliction" as a disease in which the causal pathogens were transmitted by ticks.
Regarding the producers' perceptions of the mechanisms through which ticks cause diseases, only $21 \%$ stated that ticks "transmit pathogens". Another 9\% said that a disease that ticks were capable of transmitting could appear, but that this had not yet happened. Six percent expressed suspicion that there must be "something more than just blood loss when ticks feed". The frequencies of other responses were low (Table 1).

"Affliction" occurred in 58\% of the properties, while this was absent from $38 \%$ and $4 \%$ of the farm owners were unable to say (Table 1). The owners of $50 \%$ of the farms said that only the calves were affected, but $10 \%$ cited other categories that were affected, such as heifers, cows and bulls.

In outlining the profile of producers' perceptions regarding the importance of ticks in the milk production process, it was observed that the producers in Divinópolis massively affirmed that ticks brought losses, both in weight and in the milk. However, it was noted that these losses, in these producers' view, only happened at high levels if infestation, through the blood losses caused by ticks (Table 1).This was seen in several topics that were raised, since ticks were regarded by most of the farm producers not as a pathogen transmitter but, rather, as an annihilator of the cattle's energy, through causing anemia. The complex of parasite afflictions was perceived in a large proportion of the herds, but no linkage with ticks was established.

Table 1. Producers' perceptions regarding the importance of the tick Rhipicephalus (Boophilus) microplus in the milk production process in Divinópolis, Minas Gerais, 1994.

\begin{tabular}{|c|c|c|c|c|c|c|c|c|}
\hline \multirow[t]{2}{*}{ Information $^{2}$} & \multicolumn{8}{|c|}{ Responses in order of frequency ${ }^{1}$} \\
\hline & $\mathbf{1}^{\text {st }}$ place & $\%$ & $2^{\text {nd }}$ place & $\%$ & $3^{\text {rd }}$ place & $\%$ & $4^{\text {th }}$ place & $\%$ \\
\hline Milk loss & $\begin{array}{l}\text { Affirmed that it } \\
\text { occurred }\end{array}$ & 98 & $\begin{array}{l}\text { Affirmed that it } \\
\text { did not occur }\end{array}$ & 2 & - & - & - & - \\
\hline Weight loss & $\begin{array}{c}\text { Affirmed that it } \\
\text { occurred }\end{array}$ & 100 & - & - & - & - & - & - \\
\hline Other losses & $\begin{array}{l}\text { Weakening with } \\
\text { predisposition to } \\
\text { diseases }\end{array}$ & 29 & "Causes affliction" & 20 & Anemia & 15 & Even death & 13 \\
\hline $\begin{array}{l}\text { Mechanisms through which } \\
\text { ticks are capable of causing } \\
\text { the losses cited above }\end{array}$ & Blood sucking & 96 & $\begin{array}{c}\text { Weakens; "takes away } \\
\text { the energy" }\end{array}$ & 27 & Don’t know & 4 & $\begin{array}{l}\text { Parasite } \\
\text { affliction }\end{array}$ & 2 \\
\hline $\begin{array}{l}\text { Capacity to cause increased } \\
\text { disease levels in the herd }\end{array}$ & Affirmed & 87 & Denied & 7 & Don’t know & 6 & - & - \\
\hline $\begin{array}{l}\text { Perception of diseases that } \\
\text { could increase in cattle }\end{array}$ & Anemia & 34 & Don't know & 25 & "Affliction" & 15 & $\begin{array}{c}\text { Generic } \\
\text { responses }\end{array}$ & 8 \\
\hline $\begin{array}{l}\text { Mechanisms for causing the } \\
\text { diseases cited }\end{array}$ & $\begin{array}{c}\text { Blood sucking, } \\
\text { causing weakening }\end{array}$ & 59 & Pathogen transmission & 21 & $\begin{array}{c}\text { Blood sucking and } \\
\text { transmission }\end{array}$ & 2 & - & - \\
\hline $\begin{array}{l}\text { Occurrence of "affliction on } \\
\text { the farm property" }\end{array}$ & Affirmed $^{3}$ & 58 & No & 38 & Don't know & 4 & - & - \\
\hline
\end{tabular}


In a similar way, Rocha et al. (2006) found that all of the producers interviewed in Passos, Minas Gerais, reported that ticks could cause weight and milk production losses and diseases, and that $80 \%$ said that the parasite could cause death. However, of the latter, only $12 \%$ said that mortality could be related to transmission of disease agents such as "parasite affliction".

The parameter used by $78 \%$ of the producers to determine the time to apply acaricide to the cattle was the degree of infestation. Other studies have also found that most of the producers in Minas Gerais used the same parameter, such as Amaral et al. (2011b) (96.4\%) and Rocha et al. (2006) (64\%). This is a subjective criterion that does not use any logic in control actions other than protection of the animal at that moment, and it may be very variable (LEITE; ROCHA, 1999). In most of the farm properties, the intervals between the acaricide treatments applied were the same throughout the year, which demonstrated the producers disregard for the seasonality of $R$. (B.) microplus in Minas Gerais (Table 2).
Over the year, the treatment intervals that the producers reported ranged from 8 to 180 days (mean: 24 days), with signifies application of commercial products 15 times a year. Rocha et al. (2006) found that a mean of 12 treatments were applied per year in Passos, Minas Gerais, and Vivas et al. (2006a) found the same frequency for $41.8 \%$ of the producers in Mexico, which can be considered excessive. Santos et al. (2009) found that using more than four chemical treatments per year increased the chances of selecting difficult-to-control ticks more than fourfold. Likewise, Vivas et al. (2006b) found that six or more treatments per year increased the chances of selecting resistance among ticks. Among the producers who reported applying different intervals in different seasons, the interval during the dry season ranged from 8 to 150 days (mean: 31 days), while the interval in the wet season ranged from 8 to 70 days (mean: 28 days). It was observed that the means for the diferent seasons remained close to each other, and to the mean for the whole year, which was 24 days.

Table 2. Acaricide treatment regimens for combating Rhipicephalus (Boophilus) microplus that were used by the interviewees on dairy farms in Divinópolis, Minas Gerais, 1994.

\begin{tabular}{|c|c|c|c|c|c|c|c|c|}
\hline \multirow[t]{2}{*}{ Information $^{2}$} & \multicolumn{8}{|c|}{ Responses in order of frequency ${ }^{1}$} \\
\hline & $1^{\text {st }}$ place & $\%$ & $2^{\text {nd }}$ place & $\%$ & $3^{\text {rd }}$ place & $\%$ & $4^{\text {th }}$ place & $\%$ \\
\hline Time to treat & "When there are ticks" & 78 & Some regimen & 22 & - & - & - & - \\
\hline $\begin{array}{l}\text { Interval between acaricide } \\
\text { treatments according to } \\
\text { season }\end{array}$ & $\begin{array}{c}\text { Dipping/spraying } \\
\text { throughout year, on } \\
\text { average every } 24 \text { days }\end{array}$ & 47 & $\begin{array}{l}\text { Greater frequency } \\
\text { in wet season }\end{array}$ & 27 & $\begin{array}{l}\text { Greater frequency in } \\
\text { dry season }\end{array}$ & 25 & Don’t know & 1 \\
\hline Dilution of product & $\begin{array}{l}\text { Followed the } \\
\text { instruction sheet }\end{array}$ & 66 & $\begin{array}{c}\text { Greater } \\
\text { concentration }\end{array}$ & 32 & $\begin{array}{c}\text { Smaller } \\
\text { concentration }\end{array}$ & 2 & - & - \\
\hline $\begin{array}{l}\text { Chemical basis of the prod- } \\
\text { ucts used }\end{array}$ & Amitraz & 76 & Dichlorvos & 26 & $\begin{array}{l}\text { Flumethrin } \\
\text { "pour-on" }\end{array}$ & 15 & Ivermectin & 13 \\
\hline Change of products & Not changed & 30 & $\begin{array}{l}\text { Thought it was } \\
\text { best to change } \\
\text { from time to time }\end{array}$ & 27 & $\begin{array}{l}\text { What was used did } \\
\text { not work }\end{array}$ & 27 & $\begin{array}{l}\text { Sought something } \\
\text { cheaper }\end{array}$ & 19 \\
\hline $\begin{array}{l}\text { Explanations regarding causes } \\
\text { of resistance }\end{array}$ & $\begin{array}{l}\text { "Ticks get used to the } \\
\text { medication" }\end{array}$ & 39 & $\begin{array}{l}\text { "Problem in } \\
\text { manufacturing the } \\
\text { product" }\end{array}$ & 38 & $\begin{array}{l}\text { Poorly applied } \\
\text { medication }\end{array}$ & 9 & $\begin{array}{l}\text { Prolonged use of a } \\
\text { product }\end{array}$ & 8 \\
\hline $\begin{array}{l}\text { Equipment for treatments } \\
\text { known about }\end{array}$ & Backpack pump & 99 & Bath & 54 & Cattle crush & 43 & Pour-on & 18 \\
\hline $\begin{array}{l}\text { Equipment used for } \\
\text { treatments }\end{array}$ & Backpack pump & 96 & Pour-on & 3 & Pressurized pumps & 3 & Cattle crush & 1 \\
\hline $\begin{array}{l}\text { Means of protection at the } \\
\text { time of acaricide bath }\end{array}$ & None & 40 & Do it downwind & 30 & Mask & 14 & $\begin{array}{l}\text { Avoid contact with } \\
\text { the skin }\end{array}$ & 10 \\
\hline $\begin{array}{l}\text { Animals treated on the same } \\
\text { day }\end{array}$ & All & 82 & $\begin{array}{l}\text { Only the most } \\
\text { infested ones }\end{array}$ & 11 & In batches & 5 & $\begin{array}{c}\text { The ones that are } \\
\text { nearest }\end{array}$ & 1 \\
\hline
\end{tabular}

1) the percentage corresponds to the absolute number because 100 producers participated; only the four most frequent responses have been presented; 2) each interviewee could make more than one choice and therefore the sum of the responses may be greater than 100 . 
One owner reported that during the wet season, he applied treatments only if there was a need.

By cross-correlating the variables relating to the producers' perceptions at the times of highest tick incidence and the frequency of acaricide treatments on their properties, it was seen that the frequency varied according to the time of the year (52\%), and that the time at which the intervals between treatments diminished coincided with the time at which the producers said that they had greater infestations, as also found by Rocha et al. (2006). Discordance between the two sources of information was only seen in $3 \%$ of the filled-out forms.

It is difficult to ascertain whether the producers applied treatments to the animals more frequently because they noticed greater tick infestations at certain times, or whether they concluded that there was greater infestation at these times because they noticed that the intervals were shorter. In an attempt to clarify this point, it was established that among these 52 producers who modified their frequencies of treatment seasonally, only nine of them $(17.3 \%)$ followed a regimen for combating ticks, i.e. the great majority of them (43 or $82.7 \%$ ) were treating the animals when they saw a need, according to the degree of infestation. It is therefore likely that the producers perceived the times of greater infestation through their increased workload relating to combating ticks. This demonstrates that the producers were not using strategic control technology and that they were combating ticks in a traditional manner, with intensive disorderly use of commercial products, which were used 12 to 24 times a year (VIANA et al., 1987; ROCHA et al., 2006).

High frequency of acaricide application is the main factor in establishing a resistant population of $R$. (B.) microplus through the selection pressure to which the ticks are exposed (NOLAN, 1990; SANTOS et al., 2009).

According to Bianchi et al. (2003), not only the intervals between acaricide applications but also the incorrect use of spraying products favors the onset of resistance in populations of $R$. (B.) microplus. Regarding the volume of solution required to spray/dip one animal, $45 \%$ of the producers used up to one liter. Only $18 \%$ used more than $3.5 \mathrm{~L} /$ animal and $5 \%$ had no idea how much they were using. Nonetheless, $32 \%$ of the interviewees said that they used a greater quantity of product than was indicated on the instruction sheet, i.e. a greater concentration. They did this because they thought that the acaricide was "weak" and because they wanted to try to "kill more ticks" (Table 2). Incorrect use of treatment products by large proportions of producers was also found by Vivas et al. (2006a) (27.4\%) and Rocha et al. (2006) (76\%). These findings confirm that cattle producers are managing their acaricide use inefficiently. Not only does this cause economic losses, but also it favors selection of resistant ticks. According to Amaral et al. (2011b), spraying/dipping is the most critical process within tick control and, for this reason, information should be supplied to producers regarding the correct way to carry out spraying and the best time of year to do this, as a first step in achieving regionalized strategic control.

A large proportion of the farm owners in Divinópolis reported that they used more than one commercial acaricide product simultaneously (49\%). This situation seems to have worsened, because Amaral et al. (2011a) observed the same situation among $84.2 \%$ of the producers who were using tick sensitivity tests carried out by EMBRAPA Dairy Cattle, mostly in the southeastern region $(91 \%)$. Three percent of the owners said that they used any acaricide that was commercially available (Table 2).

The products most used on the farm properties during the survey were based on amitraz (76\%), dichlorvos (26\%) and flumethrin (15\%) (Table 2). Each interviewee gave more than one option and therefore the sum of the responses was greater than $100 \%$. When asked about the acaricides used over the preceding five years, amitraz, dichlorvos and flumethrin were again cited by $39 \%$ of the farm owners. The product most reported continued to be based on amitraz (cited by $21 \%$ ), followed by deltamethrin $(5.0 \%)(15 \%)$. It was found that almost all the producers (97\%) were using and/or had previously used amitraz on their properties. This was cited frequently because the producers had a perception that this product had low toxicity and also low cost (Table 2). Vivas et al. (2006a) found that in Mexico, products based on amitraz are the ones most used by producers, although less frequently than in Brazil (40.8\%), which according to these authors might already be enough to predispose towards onset of resistance. In a test carried out at EMBRAPA, Furlong et al. (2007) found that amitraz, dichlorvos + cypermethrin and deltamethrin (the active agents most cited in their study) presented efficiency of 44, 36.1 and 15.3\%, respectively, after sensitivity tests on tick populations. These values were well below the recommended levels for acaricide products. These results emphasize the severity of the problem of resistance, given that from the low mean efficiencies recorded for these acaricides, it can only be expected that the control results will be unsatisfactory.

There was an idea among $27 \%$ of the producers that rotation of the acaricide products should be conducted. However, if this is done indiscriminately and excessively often, it may favor multiple resistance (FURLONG; MARTINS, 2000). Among the interviewees, another $27 \%$ responded that they would only change the product when it stopped working. This proportion was lower than what was found by Amaral et al. (2011a) (54.4\%), Vivas et al. (2006a) (54.1\%) and Rocha et al. (2006) (64\%), who also found that declining efficiency was the main reason for changing the product.

The owners who said that they sometimes changed the product generally had done so based on information about how to prevent resistance. Many of the owners who said that they used products that were new on the market commented that every product worked well when it first came out, but then lost its efficacy. This thinking is very logical and demonstrates that there was a clear perception that the onset of resistance is a natural phenomenon. However, new products are more related to new commercial brands than to new chemical bases. These results indicate that producers need to be guided to promote rotation of the chemical basis, and not just the products, i.e. the same chemical basis with the same mechanism of action, since selection of resistant populations occurs very rapidly (AMARAL et al., 2011a; THULLNER et al., 2007). Multiple resistance is a very frequently encountered problem in the south of Minas Gerais (DAHER, 2011).

The owners were asked about any problems that might have occurred with any acaricide product. Independent of their response, they were asked separately about "poisoning of animals", "poisoning 
of people" and/or "products that stopped working". A minority $(36 \%)$ said that they had never had such problems. The problems cited were that the "product stopped working" (45\%) and animals became poisoned $(26 \%)$. No survey of resistance in the region was conducted to check these affirmations, but this may be a real risk. Jonsson et al. (2000) in Australia and Vivas et al. (2006a) found, respectively, that 10 and $19.4 \%$ of the farms had ticks that were resistant to amitraz. The poisoning that was reported was generally associated with excessive concentrations or with the use of flumethrin (1.0\%) as a "pour-on" recommended for dry cows, when used among dairy cattle. Only $2 \%$ reported occurrences of poisoning of people through misuse of the receptacles in which the products were handled. However, 9\% commented about hypersensitive individuals who felt headaches, dizziness, nausea and/or choryza (Table 2).

To survey the producers' perceptions regarding resistance to acaricides, they were asked whether they "had ever seen or heard talk of a product that worked well against ticks on a farm property and then stopped working". The $78 \%$ who answered "yes" were then asked what the cause was. The two most frequent classes of responses related to the biology of ticks or problems with the manufacturing process of the products. This indicates that their perceptions were more related to external factors than to factors relating to their handling and use of the acaricide products. In other words, this demonstrates that the producers were impotent when faced with a process of resistance, given that they related the resistance to the biology of ticks or problems in the manufacturing processes of the products (Table 2).
In addition to the responses cited in Table 2, there were others relating to understanding of "resistance to acaricides", but it was decided to keep these separate because of the need for categorization in order to judge changes in perception. Hence, the responses have been presented in three categories: 1) responses linked to tick mechanisms; 2) responses linked to problems in manufacturing acaricide products; and 3) responses linked to problems of use and/or the producer. These are described below:

1. Responses linked to tick mechanisms: "Ticks that do not die produce the resistant ones". This response was given by only $4 \%$ of the interviewees and demonstrates a greater degree of understanding of the process of resistance onset, thus differing from the most common response, which demonstrated a notion that the owner knew that the product might become inefficient because of a tick mechanism but did not know how this happened;

2. Responses linked to problems in manufacturing acaricide products: "Lack of quality control: some come out better than others" $(2 \%)$. In this case, it was perceived that the inefficiency of the product was not seen in a constant manner: sometimes the efficacy was better than at other times. In other words, it was not seen as a process that became established but, rather, as an isolated occurrence that was solely the manufacturer's responsibility. "Fakery". Three percent reported that there had been a load of fake acaricide on the market in the region;

3. Responses linked to problems of use and/or the producer: "Poorly applied medication, neglect and misuse" were cited by $9 \%$, and "use of the same product for a long time" was

Table 3. Ways of combating Rhipicephalus (Boophilus) microplus that the dairy producers in Divinópolis, Minas Gerais, used on their farm properties, 1994.

\begin{tabular}{|c|c|c|c|c|c|c|c|c|}
\hline \multirow[t]{2}{*}{ Information $^{2}$} & \multicolumn{8}{|c|}{ Responses in order of frequency ${ }^{1}$} \\
\hline & $1^{\text {st }}$ place & $\%$ & $2^{\text {nd }}$ place & $\%$ & $3^{\text {rd }}$ place & $\%$ & $4^{\text {th }}$ place & $\%$ \\
\hline $\begin{array}{l}\text { Knowledge of combat } \\
\text { methods }\end{array}$ & $\begin{array}{c}\text { No other methods } \\
\text { known }\end{array}$ & 53 & $\begin{array}{c}\text { Pour-on products } \\
\text { and other equipment }\end{array}$ & 12 & $\begin{array}{l}\text { Treatment } \\
\text { regimens }\end{array}$ & $5 \%$ & & \\
\hline Sources of information & Veterinarians & 61 & $\begin{array}{l}\text { Neighbors and } \\
\text { friends }\end{array}$ & 24 & Salesmen & 11 & Others & - \\
\hline $\begin{array}{l}\text { Cost of baths used on the } \\
\text { property }\end{array}$ & $\begin{array}{l}\text { Thought that they were } \\
\text { using the lowest-cost } \\
\text { method }\end{array}$ & 72 & No & 27 & Don't know & 7 & & - \\
\hline $\begin{array}{l}\text { Labor for baths used on the } \\
\text { property }\end{array}$ & $\begin{array}{l}\text { Thought that they were } \\
\text { using the least labor }\end{array}$ & 69 & No & 29 & Yes & 2 & & - \\
\hline $\begin{array}{l}\text { Knowledge of ways of } \\
\text { using less labor }\end{array}$ & $\begin{array}{c}\text { The way that is it is } \\
\text { being done }\end{array}$ & 83 & Cattle crush & 8 & Others & - & & - \\
\hline $\begin{array}{l}\text { Expectation for new ways } \\
\text { of combating ticks }\end{array}$ & $\begin{array}{c}\text { Increasing the interval } \\
\text { between treatments }\end{array}$ & 60 & Decreasing the cost & 26 & $\begin{array}{l}\text { Decreasing the } \\
\text { labor }\end{array}$ & 18 & & - \\
\hline $\begin{array}{l}\text { Perceived disadvantages of } \\
\text { chemical control }\end{array}$ & None & 76 & Some & 24 & - & - & & - \\
\hline $\begin{array}{l}\text { Cost and labor as disadvan- } \\
\text { tages of acaricide baths }\end{array}$ & $\begin{array}{c}\text { Already cited both in } \\
\text { the above questions } \\
\text { above }\end{array}$ & 13 & $\begin{array}{c}\text { Cited as disadvan- } \\
\text { tages }\end{array}$ & 13 & No & 10 & One or the other & 6 \\
\hline
\end{tabular}


cited as a cause by $8 \%$. The latter was generally accompanied by a comment that the veterinarians had advised that the products should be changed. Rotation every two years is advised, or after annual follow-up with efficiency tests, which is still not a common practice among producers in Minas Gerais (DAHER, 2011).

Backpack pumps are the equipment used on $96 \%$ of the properties. The personal protection equipment (PPE) most used is a mask (14\%). These masks were mostly cloths tied across the face (Table 2). Failure to use PPE is still a reality (AMARAL et al., 2011a).

Regarding the ways of combating ticks that the producers knew about, most of them listed other equipment or products (Table 3). Some of them commented on agricultural use of abamectin, which is being used as an acaricide on animals, at a dilution of one to three parts of physiological serum, applied subcutaneously. None of the producers interviewed admitted using this product and thus no frequency of use could be measured. However, a large proportion of the producers had knowledge of this practice. On one property that did not form part of this study because of lack of access to the owner, the person in charge said that seven calves had been lost due to occurrences of a nervous condition, with salivation and dizziness in some cows after application of this product.

When asked about the costs and labor involved in control actions, the majority of the producers showed that they thought they were doing as well as they could. This was confirmed by the high frequency of lack of knowledge of other forms of control, such as strategic control, which minimizes the labor. Even when asked whether the costs and labor were disadvantages in combating ticks, few agreed. However, when asked about what they would like to improve in combating ticks, their preference was for increasing the interval between treatments. The greatest justification for choosing this was the clear reduction in labor costs. Only $13 \%$ cited toxicological risks, and these producers only referred to the risk to animals (Table 3 ).

Martins et al. (2006) cited combat methods centered on the tick ecosystem (strategic control), which could bring greater benefits to the producers. However, this is still far from the realities of the producers studied in Divinópolis, as also found in other regions of Minas Gerais by Rocha et al. (2006) and Amaral et al. (2011b). There is a clear need for diffusion of technical knowledge to the producers.

\section{Conclusions}

The production losses caused by ticks were perceived incompletely by the producers, who were unaware of the economic losses resulting from combating pathogen transmission to the animals.

The milk producers in the municipality of Divinópolis, Minas Gerais, were combating ticks with an excessive number of inefficient treatments that aimed to control the level of infestation at that moment. This favored increases in the resistance condition and exposed humans and animals to toxicological risks.
The quality of the acaricide dipping/spraying applied, particularly in the small properties, was affected by the following factors: 1) the equipment used by the producers to apply the acaricide products was backpack pumps, which makes it difficult to apply four to five liters per cow, because of the labor and time spent on the activity; 2) lack of knowledge of the mode of action of the products, which the producers often concentrate to increase their efficacy, without concern about covering the animal's entire body, through thinking that the product acts in a systemic manner, and not by contact; 3) lack of the specific information needed; and 4) lack of motivation for changing the control practices because of unawareness of the disadvantages of chemical combat.

The lack of knowledge about combat methods and the acceptance of endemicity of the parasitosis were impediments to changing the realities encountered.

\section{Acknowledgements}

The authors thank FAPEMIG (Fundação de Amparo à Pesquisa do Estado de Minas Gerais; Research Support Foundation of the State of Minas Gerais) for the support received for conducting this study.

\section{References}

AMARAL, M. A. Z. et al. Strategic Control of Cattle Ticks: milk producers' perceptions. Revista Brasileira de Parasitologia Veterinária, v. 20, n. 2, p. 148-154, 2011 a.

AMARAL, M. A. Z. et al. Perceptions and attitudes among milk producers in Minas Gerais regarding cattle tick biology and control. Revista Brasileira de Parasitologia Veterinária, v. 20, n. 3, p. 194-201, 2011 b.

BIANCHI, M. W.; BARRÉ, N.; MESSAD, S. Factors related to cattle infestation level and resistance to acaricides in Boophilus microplus tick populations in New Caledonia. Veterinary Parasitology, v. 112, n. 1-2, p. 75-89, 2003. http://dx.doi.org/10.1016/S0304-4017(02)00415-6

CAMPOS JÚNIOR, D. A.; OLIVEIRA, P. R. Avaliaçâo in vitro da eficácia de acaricidas sobre Boophilus microplus (Canestrini, 1887) (Acari: Ixodidae) de bovinos no município de Ilhéus, Bahia, Brasil. Ciência Rural, v. 35, n. 6, p. 1386-1392, 2005.

DAHER, D. O. Fatores associados à resistência do carrapato Rhipicephalus (Boophilus) microplus (Canestrini, 1887) a acaricidas no Sul de Minas Gerais. 2011. 93 f. Dissertação (Mestrado)Universidade Federal de Lavras, Lavras.

FURLONG, J.; MARTINS, J. R.; PRATA, M. C. A. O carrapato dos bovinos e a resistência: temos o que comemorar? A Hora Veterinária, v. 27, n. 159, p. 26-32, 2007.

FURLONG, J.; MARTINS, J. R. Resistência dos carrapatos aos carrapaticidas. Juiz de Fora: CNPGL-EMBRAPA, 1 ed. 2000. 25 p.

GIL, A. C. Métodos e técnicas de pesquisa social. São Paulo: Editora Atlas S.A., 1 ed. 1991. 207 p.

GRISI, L. et al. Impacto econômico das principais ectoparasitoses em bovinos no Brasil. A Hora Veterinária, v. 21, n. 125, p. 8-10, 2002.

JONSSON, N. N.; MAYER, D. G.; GREEN, P. E. Possible risk factors on Queensland dairy farms for acaricide resistance in cattle tick (Boophilus microplus). Veterinary Parasitology, v. 88, n. 1-2, p. 79-92, 2000. http://dx.doi.org/10.1016/S0304-4017(99)00189-2 
LEITE, R. C.; ROCHA, C. M. B. M. Contagens de carrapatos em bovinos no momento do banho carrapaticida em rebanhos leiteiros do Município de Divinópolis/ MG. Arquivos Brasileiros de Medicina Veterinária e Zootecnia, v. 51, n. 1, p. 41-42, 1999.

MARTINS, J. R. S.; FURLONG, J. O.; LEITE, R. C. Controle de carrapatos. In: BARROS-BATTESTI, D. M.; ARZUA, M.; BECHARA, G. H. Carrapatos de importância médico-veterinária da regiáo neotropical: um guia ilustrado para identificaçáo de espécies. São Paulo: Vox/ICTTD-3, Butantá, 2006. p. 53-113.

MINAYO, M. C. S. O desafio do conhecimento: Pesquisa qualitativa em saúde. 2. ed. São Paulo: HUCITEC; Rio de Janeiro: ABRASCO, 1993. 269 p.

NOLAN, I. Acaricide resistance in single and multi-host ticks and strategies for control. Parassitologia, v. 32, n. 1, p. 145-153, 1990.

ROCHA, C. M. B. M. Caracterizaçáo da percepçáo de produtores de leite de Divinópolis/MG sobre o carrapato Boophilus microplus e fatores determinantes das formas de combate utilizadas. 1996. 205 p. Dissertação (Mestrado)-Universidade Federal de Minas Gerais, Belo Horizonte.

ROCHA, C. M. B. M. et al. Percepçáo dos produtores de leite do município de Passos, MG, sobre o carrapato Boophilus microplus (Acari: Ixodidae). Ciência Rural, v. 36, n. 4, p. 1235-1242, 2006.

ROCHA, C. M. B. M. et al. Perceptions about the biology of Rhipicephalus (Boophilus) microplus among milk producers in Divinópolis,
Minas Gerais. Revista Brasileira de Parasitologia Veterinária, v. 20 , n. 4, p. 289-294, 2011.

SANTOS, T. R. B. et al. Abordagem sobre o controle do carrapato Rhipicephalus (Boophilus) microplus no sul do Rio Grande do Sul. Pesquisa Veterinária Brasileira, v. 29, n. 1, p. 65-70, 2009.

THULLNER, F.; WILLADSEN, P.; KEMP, D. Acaricide Rotation Strategy for Managing Resistance in the Tick Rhipicephalus (Boophilus) microplus (Acarina: Ixodidae): Laboratory Experiment with a Field Strain from Costa Rica. Journal of Medical Entomology, v. 44, n. 5, p. 817-821, 2007. http://dx.doi.org/10.1603/00222585(2007)44[817:ARSFMR]2.0.CO;2

VIANA, F. C.; CRUZ, F. E. R.; LAENDER, F. C. Diagnóstico da situação de produção bovina de leite do município de Sete Lagoas-MG. Arquivos Brasileiros de Medicina Veterinária e Zootecnia, v. 39, n. 5, p. 699-717, 1987.

VIVAS, R. I. R. et al. Prevalence and potential risk factors for amitraz resistance in Boophilus microplus ticks in cattle farms in the State of Yucatan, Mexico. Preventive Veterinary Medicine, v. 75, n. 3-4, p. 280-286, 2006a. PMid:16730819. http://dx.doi.org/10.1016/j. prevetmed.2006.04.001

VIVAS, R. I. R. et al. Prevalence and potential risk factors for organophosphate and pyrethroid resistance in Boophilus microplus ticks on cattle ranches from the State of Yucatan, Mexico. Veterinary Parasitology, v. 136, n. 3-4, p. 335-342, 2006b. PMid:16413971. http://dx.doi.org/10.1016/j.vetpar.2005.05.069 